\title{
PELUANG OPTIMALISASI PENGEMBANGAN BUDIDAYA KEPITING SOKA DI WILAYAH KIMBIS CAKRADONYA KOTA BANDA ACEH Opportunities to Optimize Soft Shell Crab Cultivation on KIMBis Cakradonya Area in Banda Aceh
}

\author{
${ }^{*}$ Freshty Yulia Arthatiani ${ }^{1}$, Estu Sri Luhur ${ }^{1}$, Armen Zulham ${ }^{1}$ dan Joni Haryadi ${ }^{2}$ \\ ${ }^{1}$ Balai Besar Penelitian Sosial Ekonomi Kelautan dan Perikanan \\ Gedung Balitbang KP I Lt. 4 \\ Jalan Pasir Putih Nomor 1 Ancol Timur, Jakarta Utara \\ ${ }^{2}$ Pusat Penelitian dan Pengembangan Perikanan Budidaya \\ Telp: (021) 64711583 Fax: 64700924 \\ "email: freshty.arthatiani@gmail.com
}

Diterima 20 Maret 2014 - Disetujui 29 Nopember 2014

\begin{abstract}
ABSTRAK
Kota Banda Aceh merupakan ibukota Provinsi Aceh yang berada di pulau Sumatera yang sangat potensial untuk pengembangan budidaya kepiting, namun masih menghadapi berbagai kendala dalam optimalisasi potensi yang dimiliki. Klinik IPTEK Mina Bisnis (KIMBis) Cakradonya di Kota Banda Aceh merupakan sebuah kelembagaan yang dibentuk pada tahun 2011 dengan tujuan peningkatan kesejahteraan masyarakat terutama di sektor kelautan dan perikanan. Tulisan ini bertujuan untuk dapat mendeskripsikan peranan KIMBis dalam mengoptimalisasi peluang pengembangan budidaya kepiting cangkang lunak yang biasa disebut kepiting soka. Penelitian dilaksanakan di Kota Banda Aceh yang merupakan wilayah Kerja KIMBis Cakradonya dengan analisis data dilakukan secara deskriptif kualitatif untuk menjelaskan kegiatan yang telah dilaksanakan oleh KIMBis dalam mengoptimalkan peluang pengembangan usaha kepiting soka. Hasil penelitian menunjukkan KIMBis Cakradonya berperan dalam mensosialisasikan peluang usaha kepiting soka terutama kepada stakeholders sehingga diharapkan dapat memberikan dukungan kebijakan bagi pengembangan usaha ini, selain itu KIMBis juga berperan dalam memperkenalkan penggunaan teknologi budidaya kepiting soka dan pengolahan limbah hasil budidaya kepiting yang diharapkan dapat meningkatkan produktivitas usaha. Namun optimalisasi peluang pengembangan kepiting soka mengalami berbagai kendala dari sisi teknologi, sumberdaya manusia modal dan juga input produksi. Oleh karena itu kedepannya diharapkan dapat dilaksanakan upaya tindak lanjut untuk mengatasi berbagai kendala yang dihadapi baik itu dari sisi pengadaan benih kepiting, maupun aplikasi penerapan teknologi yang efisien serta peningkatan kemampuan pembudidaya kepiting soka dalam mengakses permodalan sehingga usaha ini dapat berkembang secara optimal bagi peningkatan kesejahteraan masyarakat.
\end{abstract}

Kata Kunci: kepiting, soka, Banda Aceh, KIMBis

\begin{abstract}
Banda Aceh is the capital of Aceh Province that has great potential in crab cultivation. Klinik IPTEK Mina Bisnis (KIMBis) Cakradonya in Banda Aceh is an institution established in 2011 with the aim of improving the welfare of the community, especially in the marine and fisheries sector. This paper aims to describe the role of KIMBis to optimize the chances of developing soft shell crab farming on Banda Aceh. This research was conducted in Banda Aceh with qualitative descriptive data analysis methods. The results showed that KIMBis Cakradonya has role in disseminating of soft-shelled crabs business opportunities especially to the stakeholders that are expected to provide policy support. KIMBis also had a role in the activities of introducing the use of soft-shelled crab cultivation technology and waste treatment of cultured crabs to increase business productivity. However, the development of soft-shelled crabs are still constrained in terms of technology, human resources and capital inputs. Therefore, in the future is expected to be implemented in various ways to overcome the problems in the soft shell crab cultivation such as crab seed procurement, as well as the application of efficient application of technology and the increased capacity in the soft-shelled crab farmers to access capital so that businesses can develop optimally for improvement public welfare.
\end{abstract}

Keywords: crab, soft shell, Banda Aceh, KIMBis 


\section{PENDAHULUAN}

Kepiting merupakan salah satu komoditas perikanan bernilai ekonomis tinggi. Kepiting soka atau biasa juga disebut dengan istilah kepiting fase ganti kulit (moulting). Pengembangan budidaya kepiting bakau cangkang lunak ini merupakan diversifikasi produksi untuk menjawab tantangan pasar luar negeri. Data dari Direktorat Jenderal P2HP KKP pada tahun 2011 volume ekspor kepiting mencapai 23.089 ton dan mengalami tren yang cenderung meningkat tiap tahunnya namun di sisi lain data dari Direktorat Jenderal Perikanan Budidaya menunjukkan bahwa produksi kepiting bakau hasil budidaya berfluktuasi tiap tahunnya sehingga hal tersebut dapat mengindikasikan adanya kelemahan dari sisi produksi budidaya kepiting dibandingkan tingkat permintaan dari pasar yang cenderung meningkat.

Balai Besar Penelitian Sosial dan Ekonomi Balitbang Kelautan dan Perikanan (BBPSEKP) merancang sebuah lembaga advokasi yang dikenal sebagai Klinik IPTEK Mina Bisnis (KIMBis) yang merupakan sebuah lembaga masyarakat kelautan dan perikanan, yang dibentuk secara partisipatif oleh berbagai pemangku kepentingan, untuk mendorong kemandirian masyarakat pedesaan dalam merebut berbagai peluang untuk mewujudkan kesejahteraan. KIMBis Cakradonya di Kota Banda Aceh dibentuk sejak tahun 2012 .

Hasil identifikasi dari kegiatan kelompok sasaran KIMBis Cakradonya Kota Banda Aceh menunjukan bahwa budidaya kepiting soka merupakan salah satu kegiatan andalan ekonomi masyarakat budidaya yang sudah berkembang sangat baik. Produksi hasil budidaya kepiting soka Kota Banda Aceh sangat diminati oleh pembeli lokal (Medan, Jakarta, Surabaya, dan Bali) dan pembeli mancanegera (Amerika, Jepang, Hongkong, Taiwan, Malaysia dan Thailand). Informasi dari responden menyebutkan bahwa hal ini disebabkan oleh tingginya kualitas (kadar air $\leq 10 \%$ ) dan rasa produk kepiting soka hasil pembudidaya Kota Banda Aceh di bandingkan dengan kawasan lain di Indonesia.

Permintaan pasar terhadap kepiting soka terus meningkat sedangkan kondisi kepiting soka yang dihasilkan langsung dari alam terus menurun baik dari segi ukuran dan jumlah. Salah satu permintaan pasar dari pembeli di Jepang yang telah ditawarkan kepada pembudidaya kepiting cangkang adalah dengan jumlah minimum 4 ton per bulan dan kisaran harga Rp. 120.000 per $\mathrm{kg}$, namun pembudidaya belum dapat memenuhi tawaran tersebut karena keterbatasan dari sisi produksi. Hal ini merupakan peluang dan tantangan bagi pembudidaya dan pemerintah Kota Banda Aceh dalam mengembangkan potensi lahan pesisir daerah dan perekonomian masyarakat kawasan KIMbis Cakradonya Kota Banda Aceh secara optimal. Namun hal ini belum dapat dipenuhi oleh pembudidaya kepiting soka di Kota Banda Aceh yang disebabkan karena berbagai kendala yang dihadapi dalam kegiatan produksi kepiting soka.

Tujuan terbentuknya KIMBis adalah untuk mewujudkan tumbuh dan berkembangnya lembaga yang mampu menumbuhkan kewirausahaan dalam masyarakat dengan memanfaatkan IPTEK dalam peningkatan kesejahteraan mereka. Fungsi KIMBis sebagai sarana pemberdayaan masyarakat dengan memanfaatkan IPTEK.Sarana pengembangan ekonomi masyarakat yang memanfaatkan IPTEK menjadikan KIMBis dapat berfungsi untuk mengoptimalkan peluang pengembangan budidaya kepiting soka di Kota Banda Aceh sehingga dapat memenuhi permintaan pasar dan juga sebagai sarana pengembangan ekonomi masyarakat Kota Banda Aceh. Upaya optimalisasi peluang pengembangan kepiting soka yang dapat dilakukan melalui kegiatan KIMBis Cakradonya diantaranya melalui kegiatan sosialisasi peluang pengembangan budidaya kepiting soka yang dilakukan oleh praktisi khusus di bidang budidaya kepiting soka kepada stakeholders dilingkup Pemerintahan Kota Banda Aceh sehingga terdapat dukungan kebijakan yang menunjang usaha budidaya kepiting soka. Selain hal tersebut juga telah dilaksanakan berbagai pengawalan teknologi yang mendatangkan ahli di bidang budidaya kepiting soka yang diharapkan dapat meningkatkan kapasitas sumberdaya manusia terutama dari sisi penguasaan teknologi.

Selain hal tersebut dukungan KIMBis sebagai sebuah lembaga advokasi bagi masyarakat terutama di sektor kelautan dan perikanan yang ingin memanfaatkan peluang budidaya kepiting soka di Kota Banda Aceh, Namun peranan KIMBis Cakradonya dihadapkan pada berbagai kendala sehingga perlu untuk dilakukan penelitian untuk menganalisis sejauh mana peranan KIMBis dalam upaya optimalisasi peluang pengembangan usaha budidaya kepiting soka di Kota Banda Aceh. Hal ini diharapkan dapat meningkatkan peran KIMBis Cakradonya sekaligus sebagai sebuah 
umpan balik kepada pengambil kebijakan untuk dapat melakukan langkah strategis sehingga budidaya kepiting soka di Kota Banda Aceh dapat optimal. Berdasarkan latar belakang tersebut di atas, makalah ini bertujuan untuk menggambarkan peranan KIMBis Cakradonya dalam mengoptimalisasi peluang usaha budidaya kepiting soka di Kota Banda Aceh sehingga dapat diketahui sejauh mana peranan KIMBis terutama dalam pengembangan budidaya kepiting soka di Kota Banda Aceh.

\section{METODOLOGI}

\section{Lokasi dan Waktu Penelitian}

Penelitian ini dilakukan di Kota Banda Aceh yang merupakan lokasi wilayah kerja KIMBis Cakradonya. Penelitian ini dilakukan dalam waktu tujuh bulan, yaitu dari bulan Maret hingga September 2013

\section{Sumber data dan Instrumen Penelitian}

Berdasarkan sumbernya, data yang diperlukan dalam penelitian ini berupa data primer dan data sekunder. Data primer merupakan data informasi yang diperoleh dari hasil diskusi dan wawancara dengan stakeholders. Data primer diperoleh dari wawancara langsung menggunakan topik data dengan informan kunci seperti para pelaku usaha perikanan, pejabat terkait usaha Budidaya Kepiting soka di Kota Banda Aceh. Selain itu, data sekunder merupakan data teks berupa keterangan mengenai data-data lain yang relevan dengan penelitian ini. Data sekunder yang dikumpulkan berupa data produksi kepiting di Indonesia, data pemasaran kepiting, data luas areal lahan potensi dan budidaya kepiting di Banda Aceh dan berbagai data lain yang diperoleh melalui instansi Direktorat Jenderal Perikanan Budidaya, Direktorat Jenderal P2HP, BPS dan Dinas Kelautan Pertanian dan Peternakan Kota Banda Aceh.

\section{Metode Analisis Data}

Penelitian yang dilakukan meliputi perancangan penelitian, perumusan masalah, pengumpulan data dari berbagai instansi terkait, pengolahan data, analisis data, interpretasi data, dan penarikan kesimpulan. Analisis data dalam penelitian ini menggunakan pendekatan kualitatif yang dijelaskan secara deskriptif berdasarkan data primer dan sekunder yang telah diperoleh untuk menggambarkan peranan KIMBis Cakradonya dalam mengoptimalisasi peluang usaha budidaya kepiting soka di Kota Banda Aceh. Analisis data kualitatif menurut Patton ${ }^{6}$ adalah proses mengatur urutan data serta mengorganisasikanya ke dalam pola, kategori dan satuan uraian dasar. Teknik analisis SWOT juga digunakan dalam memformulasikan strategi yang tepat untuk mengoptimalisasi budidaya kepiting soka di Kota Banda Aceh.

\section{POTENSI DAN PELUANG PENGEMBANGAN KEPITING SOKA}

Kepiting merupakan salah satu komoditas perikanan bernilai ekonomis tinggi. Tren permintaan ekspor kepiting yang cenderung meningkat tidak diimbangi dengan kemampuan budidaya kepiting sehingga menyebabkan produksi kepiting belum dapat memenuhi permintaan pasar (Siahainenia, 2008). Salah satu jenis kepiting yang memiliki prospek terus meningkat adalah kepiting bakau (Scylla Seratta). Kepiting tersebut hidup pada habitat perairan pantai, khususnya di daerah hutan mangrove. Kepiting bakau (scylla sp) adalah salah satu komoditas perikanan pada habitat perairan pantai, khususnya di daerah hutan mangrove. Dengan adanya kawasan hutan mangrove di seluruh wilayah pantai Nusantara menjadikan negara Indonesia sebagai pengekspor kepiting bakau yang cukup besar dibandingkan negara pengekspor lainnya. Kepiting bakau memiliki potensi nilai ekonomis di wilayah Indo-Pasifik, karena memiliki rasa daging yang enak dan kandungan gizi yang tinggi (Susanto, 2008).

Kepiting bakau cangkang lunak adalah kepiting bakau fase ganti kulit (moulting) atau biasa disebut dengan kepiting soka. Kepiting dalam fase ini mempunyai keunggulan yaitu mempunyai cangkang yang lunak (soft shell mud crab) sehingga dapat dikonsumsi secara utuh (Nurdin dan Armando 2010). Pengembangan budidaya kepiting bakau cangkang lunak merupakan bentuk diversifikasi produksi untuk menjawab permintaan pasar. Kendala penguasaan teknik produksi sering dialami dalam produksi kepiting bakau cangkang lunak karena memerlukan metode khusus untuk memoltingkan kepiting tersebut dan proses percepatan ganti kulit.

Kota Banda Aceh merupakan salah satu kawasan potensial untuk pengembangan usaha perikananan. Data dari BPS Kota Banda Aceh menunjukkan bahwa 5 (lima) dari 9 (sembilan) kecamatan di Kota Banda Aceh merupakan 
kawasan pesisir (sepanjang $17 \mathrm{~km}$ dengan luas perairan $144.000 \mathrm{~km}^{2}$ ) sehingga sangat potesial untuk menjadi fokus dari upaya pengembangan ekonomi masyarakat. Kawasan ini diharapkan dapat dikembangkan sebagai tempat berbagai aktivitas perikanan dan perdagangan komoditas dan produk perikanan. Menurut Dinas Kelautan dan Perikanan Provinsi Aceh, luas lahan usaha budidaya di Kota Banda Aceh adalah 632,5 ha yang terdiri dari luas tambak 628,6 ha, kolam 3 ha dan karamba 1 ha pada tahun 2011. Luas lahan usaha budidaya yang sudah dikelola sebesar 240 ha, namun masih tersedia 350 ha tambak yang belum berfungsi karena terbatasnya modal untuk memperbaikinya. Tambak rakyat yang belum diperbaiki terdapat di Gampong Pande dan di Ulee Lheu.

Kegiatan budidaya kepiting soka sudah berjalan dengan baik di Kota Banda Aceh terutama di Desa Lamjabat, Kecamatan Meuraxa. Bentuk produk kepiting yang hasilkan adalah softshell kepiting soka. Luas kawasan budidaya kepiting soka adalah 1 ha berhadapan langsung dengan pesisir pantai Lamjabat. Sumber benih kepiting soka yang dibudidaya berasal dari tangkapan liar dengan berat 70 gram per ekor. Setelah dipelihara selama 15 - 20 hari, kepiting softshell akan dipanen dan siap dipasarkan dengan harga Rp. 90.000 Rp. 120.000 per kg sesuai dengan ukuran berat yang dipesan. Dari segi teknik budidaya dan pasar, kepiting soka sudah cukup dikuasai oleh kelompok pembudidaya kepiting meskipun teknologi yang digunakan masih bersifat tradisional dan dipelajari secara otodidak. Pasar kepiting soka softshell dari kelompok pembudidaya di Desa Lamjabat adalah ke Kota Medan dan kemudian dikirim oleh perusahan di Medan ke Amerika Serikat.

Budidaya kepiting soka di Kota Banda Aceh masih dihadapkan dengan keterbatasan populasi anak kepiting di cangkang lunak di alam. Untuk mengatasi persoalan keterbatasan benih alam yang terus berkurang, maka teknik perbenihan kepiting soka dapat diperkenalkan sebagai solusi mengatasi masalah perbenihan kepiting soka. Sugama (2013) menyatakan bahwa terdapat peluang pasar yang potensial bagi budidaya kepiting bakau terutama ke pasar Singapore, Hongkong, Taiwan, Uni Eropa, USA, China dan Jepang dengan kisaran harga kepiting soka mencapai US\$ 6-10/kg. Permintaan kepiting soka yang terus meningkat baik dari pasar domestik dalam negeri maupun dari negara Jepang, Singapore Taiwan dan China serta tingkat harga yang kompetitif menjadikan industri kepiting soka menjadi makin popular dan prospektif.
Peluang pengembangan budidaya kepiting soka masih terbuka luas di Kota Banda Aceh. Informasi dari responden menyebutkan bahwa rasa produk kepiting soka hasil pembudidaya kota banda Aceh di bandingkan dengan kawasan lain di Indonesia menyebabkan permintaan pasar terhadap kepiting soka asal Banda Aceh menjadi tinggi. Hal ini juga diimbangi dengan masih potensialnya lahan tambak dengan kondisi alam yang mendukung untuk dikembangkan sebagai areal budidaya kepiting soka. Dengan teknik budidaya yang sebagian sudah dikuasai oleh pembudidaya di Banda Aceh menyebabkan pengembangan kepiting soka menjadi sangat prospektif dalam upaya peningkatan kesejahteraan masyarakat.

\section{PERAN KIMBIS DALAM PENGEMBANGAN KEPITING SOKA}

\section{Sosialiasi dan Advokasi Pemanfaatan Peluang Pengembangan Kepiting Soka dengan SKPD di Provinsi Aceh}

KIMBis Cakradonya Kota Banda Aceh dan Balai Besar Penelitian Sosial Ekonomi Kelautan dan Perikanan melakukan kegiatan sosialisasi peluang pengembangan usaha budidaya kepiting soka yang bertempat di Kantor Wali Kota Banda Aceh dengan peserta Kepala Dinas Provinsi dan Kabupaten dan Kota di Provinsi Aceh yang membidangi kelautan dan perikanan. Selain itu juga diundang Kepala Unit Pelaksana Teknis Pusat dan Daerah diantaranya Balai Budidaya Air Payau (BBAP) Ujong Batee dan UPTD Budidaya Air Tawar (BAT) Jantho Baru Kabupaten Aceh Besar, serta para pelaku usaha perikanan yang ada di Kota Banda Aceh. Kegiatan sosialisasi ini menghadirkan praktisi khusus yang berpengalaman dalam budidaya perikanan dan terutama usaha budidaya kepiting soka. Tujuan dari dilaksanakanya kegiatan ini adalah untuk memberikan informasi kepada stakeholders terkait di Provinsi Aceh bagaimana prospek usaha kepiting soka, berikut teknologi dan kendala apa yang dihadapi dalam pengembanganya. Setelah pelaksanaan kegiatan ini diharapkan para pengambil kebijakan memiliki pemahaman terhadap peluang pengembangan budidaya kepiting soka sehingga kebijakan yang diambil dapat mendorong peluang pengembangan usaha ini untuk peningkatan kesejahteraan masyarakat.

Kegiatan sosialisasi peluang pengembangan usaha budidaya kepiting soka telah memberikan kontribusi yang sangat baik kepada pemerintah 
daerah Provinsi Aceh dan Kabupaten dan Kota yang hadir pada acara sosialisasi tersebut. Berdasarkan hasil diskusi dan pemaparan dari narasumber pengembangan budidaya kepiting soka dalam skala besar dan kurun waktu yang panjang dikawasan Kota Banda Aceh menghadapi kendala ketersediaan bibit kepiting soka. Salah satu solusi yang efektif dan efesien adalah membangun hatchery perbenihan kepiting soka dan menyiapkan kawasan nursery ground dengan mangrove yang baik. Dalam produksi benih kepiting cangkang lunak, Balai Besar Air Payau (BBAP) Ujung Batee Ujung Batee telah bersedia dimanfaatkan secara optimal untuk memenuhi kebutuhan benih kepiting soka Kota Banda Aceh. Hasil benih yang diproduksi oleh BBAP Ujung Batee akan diserahkan kepada masyarakat yang berada di kawasan mangrove dan dikelola, dipelihara secara berkelompok. Pola tangkap terhadap kepiting soka sebagai bakalan akan ditentukan berdasarkan jumlah dan berat kepiting soka oleh pengelola dan di awasi oleh Dinas Kelautan dan Perikanan Kota Banda Aceh. Namun realisasi dari wacana tersebut diatas membutuhkan komitmen yang kuat dari berbagai pihak yang berkepentingan sehingga kedepanya peluang kepiting soka yang dapat dibudidayakan di Provinsi Aceh dapat dikembangkan secara optimal.

\section{Pengenalan Teknologi Budidaya Kepiting Soka}

Teknologi budidaya kepiting soka yang sudah diterapkan pembudidaya kepiting di Banda Aceh saat ini masih bersifat tradisional dengan pemenuhan bibit yang berasal dari alam. KIMBis Cakradonya melakukan kegiatan sosialisasi tentang penerapan berbagai teknologi yang dapat digunakan dalam upaya pengembangan budidaya kepiting soka. Salah satunya adalah melalui teknologi Integrated Multi Tropic Aquaculture (IMTA). Teknologi ini dasarnya merupakan sistem budidaya yang seimbang dan saling menguntungkan dengan menggunakan komoditas-komoditas yang saling memanfaatkan relung dan nutrient serta aliran energi. Prinsip multi tropik akuakultur adalah zero waste, artinya input pakan hanya diberikan kepada komoditas target yang memiliki nilai ekonomis tinggi, sedangkan sisa pakan dan semua nutrient sisa budidaya dimanfaatkan oleh komoditas level berikutnya yang secara kuantitatif jauh lebih banyak dari komoditas target yang feed cost nya adalah nol.

Dengan komoditas yang bukan target ini diharapkan mampu memberi multiefek yang besar terhadap penyerapan tenaga kerja dan penyediaan bahan protein ikan kompetitif karena ongkos produksinya yang murah, dan fungsi komoditas non target berperan sebagai pembersih limbah budidaya meningkatkan kelestarian lingkungan. Pengembangan kepiting soka dengan teknologi IMTA menggunakan komoditas tambahan ikan bandeng dan rumput laut. Diperkenalkanya teknologi ini diharapkan dapat meningkatkan usaha yang dilakukan pembudidaya karena dapat menghasilkan komoditas tambahan berupa ikan bandeng dan rumput laut. Untuk pengenalan teknologi IMTA pada budidaya kepiting soka, KIMBis Cakradonya memfasilitasi implementasi teknologi ini dengan memberi contoh teknik budidaya tersebut yang diterapkan pada tambak terpilih menjadi lokasi contoh sehingga kelompok sasaran dapat memahami dengan lebih baik bagaimana teknologi tersebut diterapkan.

Selain itu teknologi lain yang disosialisasikan adalah teknologi hatchery (pembibitan) kepiting bakau dan teknologi pemberian ekstrak Bayam (Amaranthus spp). Teknologi hatchery diharapkan dapat mengatasi kelangkaan benih kepiting yang selama ini hanya tersedia di alam, selain itu benih dari hasil hatchery diharapkan dapat mengurangi kemungkinan terserang protozoa dan penyakit yang banyak ditemukan pada benih yang berasal dari alam. Sedangkan pemberian ekstrak bayam untuk usaha budidaya kepiting digunakan untuk memperlancar molting (ganti kulit). Ekstrak ini mengandung ekdisteroid hormon dimana setelah 4-16 suntikan Ekstrak bayam dapat mempercepat proses moulting hingga $80 \%$. Namun kedua teknologi tersebut hanya disosialisasikan kepada pemangku kepentingan dan juga pelaku usaha dan belum dilakukan implementasi bagaimana penggunaan teknologi tersebut. Akan tetapi sosialisasi teknologi tersebut diharapkan dapat memberikan informasi bagi stakeholders terkait optimalisasi budidaya kepiting soka karena memberikan alternatife teknologi yang dapat digunakan untuk mengatasi berbagai kendala dalam budidaya kepiting soka.

\section{Pengenalan Teknologi Pengolahan Limbah Hasil Budidaya Kepiting Soka}

Usaha budidaya kepiting soka menghasilkan limbah padat berupa cangkang kepiting soka hasil dari moulting dan kaki dari kepiting tersebut. Limbah cangkang ini tersedia sekitar $30 \mathrm{~kg}$ per hari dalam bentuk basah. Sampai dengan saat ini, limbah cangkang kepiting ini belum dimanfaatkan 
karena dianggap tidak berguna . Ellis dan Mantel (1985) dalam Multazam (2002) menyatakan bahwa dalam limbah cangkang kepiting beserta sisa daging yang masih melekat pada cangkang mengandung protein, lemak, pigmen, garam kalsium, kitin, serat kasar dan mineral (fosfor, kalsium, magnesium, tembaga, besi, seng dan mangan). Secara komersial, potensi pemanfaatan limbah ini adalah sebagai bahan baku pembuatan chitosan pada industri farmasi. Berdasarkan hasil uji laboratorium yang dilakukan, kadar kalsium dalam cangkang kepiting ini sangat tinggi yaitu mencapai 9.000 mg. Kadar kalsium tersebut sangat memenuhi syarat dalam pembuatan chitosan. Selain untuk bahan chitosan, tepung dari cangkang kepiting ini dapat dimanfaatkan sebagai bahan dalam pembuatan pakan ikan sehingga limbah cangkang kepiting ini dapat dipasarkan ke pabrikpabrik pakan dan ke industri farmasi. Karakteristik usaha pemanfaatan limbah dari hasil dari budidaya kepiting soka di Kota Banda Aceh berdasarkan data primer dapat diketahui bahwa rata-rata tiap harinya tersedia 30 kilogram cangkang kepiting yang tidak termanfaatkan sehingga potensial untuk diusahakan untuk bahan pakan ikan maupun usaha lain seperti industri farmasi untuk menghasilkan chitosan yang memiliki nilai ekonomis.

Kegiatan pengawalan teknologi pemanfaatan limbah hasil perikanan dilaksanakan oleh KIMBis Cakradonya Kota Banda Aceh sebagai salah satu bentuk kegiatan dalam mendukung usaha budidaya kepiting soka karena didasari oleh potensi limbah yang dihasilkan dari usaha ini. Limbah menurut Harahap et al. (2011) adalah buangan yang dihasilkan dari suatu proses produksi yang kehadiranya tidak dikehendaki lingkungan karena tidak memiliki nilai ekonomis. Kegiatan perikanan biasanya menghasilkan limbah berupa bahan daging ikan, tulang ikan, kulit ikan, kepala ikan dan jeroan ikan yang dapat dimanfaatkan serta limbah ikan dan komoditas budidaya lain yang mati atau terbuang pada saat proses produksi terjadi.

Pada kegiatan tersebut peserta yang mengikuti pengawalan teknologi berasal dari kelompok masyarakat pengolah hasil perikanan, kelompok masyarakat pembudidaya dan kelompok masyarakat di sekitar kawasan pesisir kota Banda Aceh Adapun narasumber dalam pendampingan ini merupakan peneliti yang sudah berpengalaman dalam memberikan materi terkait pengolahan limbah hasil perikanan. Narasumber tersebut diharapkan memiliki kemampuan yang cukup dan pengalaman yang memadai untuk dapat memfasilitasi peserta pengawalan teknologi sehingga tujuan dari pelaksanaan kegiatan dapat tercapai. Materi disampaikan secara demonstratif dan partisipatif terhadap peserta, ditunjukkan dengan praktek langsung penggunaan sehingga efektivitas pelaksanaan kegiatan dapat diselenggarakan dengan baik. Limbah perikanan masih banyak belum termanfaatkan.

Limbah dari usaha budidaya kepiting soka biasanya berupa cangkang dan capit dari kepiting yang dibudidayakan, limbah tersebut diperoleh dari proses pemotongan capit kepiting dan juga proses moulting serta adanya beberapa kepiting soka yang mati selama siklus budidaya. Sebagai gambaran umum untuk skala produksi 1500 kg/ bulan limbah kepiting sokanya mencapai $200 \mathrm{~kg}$ per bulan dalam bentuk kering

Kegiatan pemanfaatan limbah hasil perikanan ini mengajarkan peserta untuk membuat produk dari limbah hasil perikanan baik berupa tepung ikan yang berbahan baku dari cangkang kepiting. Proses pembuatan tepung ikan berbahan baku cangkang kepiting yang telah dikeringkan dan dihaluskan yang kemudian direbus dalam beaker glass atau dalam hal ini dapat digunakan alat serupa yang dapat berfungsi menghantarkan panas seperti. Cangkang kepiting yang telah direbus dengan suhu $90^{\circ} \mathrm{C}$ selama 1 jam ke dalam air yang sudah dicampur dengan $\mathrm{NaCl}$. Kemudian cangkang tersebut disaring hingga semua larutan terbuang kemudian dijemur hingga benar-benar kering. Kemudian ditumbuk hingga halus lalu dihasilkanlah tepung kalsium ikan. Tepung ini dapat digunakan sebagai bahan campuran dalam pakan ikan maupun pakan ternak.

Kegiatan tersebut menjadi sangat bermanfat bagi peserta dikarenakan teknologi yang digunakan relatif sederhana. Namun disisi lain perlu adanya tindak lanjut dari pengawalan teknologi yang dilakukan dengan pemberian akses terhadap informasi pasar untuk produk-produk hasil olahan limbah yang potensial untuk dapat digunakan. Informasi pasar tersebut terkait pasar tujuan pelaku usaha dan pengembangan prospek usaha secara ekonomis.

\section{STRATEGI PENGEMBANGAN BUDIDAYA KEPITING SOKA}

Kegiatan yang dilaksanakan oleh KIMBis Cakradonya yang telah disebutkan diatas bertujuan untuk mendukung optimalisasi pemanfaatan peluang pengembangan budidaya 
kepiting soka di Banda Aceh. Namun berdasarkan hasil pelaksanaan kegiatan dan penelitian yang dilakukan dapat diketahui bahwa peluang pengembangan budidaya ini mengalami berbagai kendala. Kendala tersebut secara garis besar dikelompokkan menjadi kendala teknologi, kendala modal, kendala sumberdaya manusia dan kendala input produksi.

Kendala teknologi yang dihadapi adalah masih belum dikuasainya teknologi modern budidaya kepiting soka sehingga teknologi yang diterapkan masih bersifat tradisional. Ketersediaan pakan bersumber dari tangkapan alam sehingga kontinuitas volume produksi belum dapat terjamin. Teknologi yang digunakan selama ini diperoleh secara turun temurun, meskipun dari sisi tingkat mortalitas rendah namun di sisi lain efisiensi produksi masih belum dicapai secara optimal, apalagi jika dibandingkan dengan teknologi dari negara pesaing seperti di Vietnam, China, Philipina, Australia, India dan Malaysia yang telah mengembangkan teknologi hatchery berupa soft shell rass sytem. Sebagai contoh di Jepang, beberapa hatchery telah memproduksi benih kepiting dalam skala besar. Tujuan dan usaha ini adalah untuk "re-stocking", yaitu benih kepiting ditebar ke iaut dengan dengan harapan dapat memulihkan atau meningkatkan hasil perikanan laut. Program di Jepang ini disebut "Saibai gyogyo" yang dimulai di laut Seto Inland (Seto Insland Sea) pada pertengahan 1960 dengan penebaran benih udang (Juwana, 1992). Namun teknologi tersebut diatas hingga saat ini belum mampu diterapkan di Indonesia sehingga belum mampu mengatasi kendala utama dari budidaya kepiting yakni keterbatasan benih kepiting yang bergantung pada ketersediaan benih dari alam.

Modal juga menjadi faktor yang penting dalam usaha budidaya kepiting soka. Berdasarkan data yang diperoleh dari pembudidaya kepiting soka di Banda Aceh, biaya investasi yang diperlukan adalah sebesar Rp. 272.855.000,- per hektar dengan asumsi lahan sewa yang digunakan. Besarnya biaya investasi tersebut menjadi kendala tersendiri dalam mengembangkan usaha ini. Meskipun kenyataan di lapangan diketahui bahwa pelaku usaha sudah banyak mendapatkan bantuan berupa alat-alat produksi seperti basket dan freezer dari berbagai program berbantuan baik dari pemerintah daerah maupun pemerintah pusat namun hal ini masih belum dapat menarik minat masyarakat untuk menjalankan usaha budidaya kepiting soka secara optimal. Program berbantuan tersebut sebagian hanya dimanfaatkan oleh beberapa pembudidaya yang benar-benar melakukan usahanya, sehingga efek multipliemya belum terasa bagi optimalisasi peluang yang dimiliki dalam pengembangan budidaya kepiting soka.

Sumberdaya manusia juga menjadi kendala tersendiri dalam menentukan keberhasilan budidaya kepiting soka. Teknik budidaya kepiting soka banyak dipelajari secara otodidak dan sifatnya masih tradisional yang diterapkan oleh pembudidaya di Banda Aceh. Oleh karena itu peyebaran kemampuan untuk membudidayakan kepiting soka relatif masih rendah, karena belum banyak sumberdaya manusia yang mengusai teknik budidaya tersebut. Penguasaan teknik budidaya kepiting soka akan berperan dalam menentukan teknik pemotongan capit kepiting, dimana pematahan atau pemotongan kaki jalan dan capit kepiting bertujuan untuk menghindari kepiting saling memangsa dan keluar dari keranjang serta merangsang percepatan proses moulting. Selain itu hal lain yang perlu dipahami dengan baik oleh sumberdaya manusia yang melakukan usaha di bidang ini adalah pemberian pakan dan jenis pakan. Dosis pemberian pakan kepiting soka berkisar 4-6\% dari biomasa dengan frekuensi pemberian satu kali dalam sehari. Hal ini sesuai dengan pendapat Cholik et al., (2005) yang menyatakan bahwa sebaiknya pemberian pakan kepiting dilakukan pada sore hari atau menjelang malam karena kepiting bakau aktif mencari makan pada saat matahari sehingga jika hal ini tidak dipahami dengan baik akan sangat menentukan keberhasilan budidaya. Pengetahuan akan hama dan penyakit dan penanganan panen dan pasca panen juga menjadi hal yang wajib untuk diketahui bagi pelaku usaha. Sehingga dalam budidaya kepiting soka terbatasnya kualitas sumberdaya manusia yang memahami teknik budidaya menjadi kendala tersendiri bagi pengembangan usaha ini.

Input produksi yang menjadi kebutuhan utama dalam menjalankan usaha budidaya kepiting soka adalah ketersediaan bibit atau benih kepiting. Kondisi riil di Banda Aceh menunjukkan bahwa benih kepiting hanya diperoleh berdasarkan hasil tangkapan dari alam, hal ini menyebabkan sangat sulit tercapai kontinuitas produksi dalam usaha budidaya kepiting. Permintaan dari pembeli biasanya menekankan pada kontinuitas produksi 
dan kualitas yang konsisten sehingga kendala dalam hal ketersediaan benih sangat dirasakan bagi pembudidaya. Hal ini menyebabkan pembudidaya belum bisa memenuhi permintaan pasar terutama dari luar negeri meskipun harga yang ditawarkan sangat tinggi. Data dari responden menyebutkan bahwa produksi budidaya kepiting soka di Kota Banda Aceh selalu terserap oleh pasar dengan harga yang relatif tinggi yaitu berkisar antara Rp.90.000 - Rp 120.000,- per kilogram, namun di sisi lain pembudidaya kesulitan meningkatkan kapasitas produksinya karena keterbatasan input produksi. Berbagai kendala yang disebutkan diatas membuat peluang pengembangan budidaya kepiting soka yang masih prospektif di Kota Banda Aceh belum optimal dimanfaatkan dalam tujuan peningkatan kesejahteraan masyarakat.

Strategi yang dapat dirumuskan berdasarkan hasil analisis dan pengumpulan data primer dan sekunderdariusaha kepiting soka diKotaBandaAceh dirumuskan dengan menggunakan analisis SWOT. Analisis SWOT adalah indentifikasi berbagai faktor secara sistematis untuk merumuskan strategi suatu sistem (perusahaan). Analisis ini didasarkan pada logika yang dapat memaksimalkan kekuatan dan peluang, secara bersamaan dapat meminimalkan kelemahan dan ancaman (Rangkuti, 2000). Nickols (2000) menjelaskan bahwa strategi dapat diartikan dalam beberapa hal seperti rencana, pola, posisi, serta pandangan. Sebagai rencana, strategi berhubungan dengan bagaimana memfokuskan

Perhatian dalam mewujudkan tujuan yang ingin dicapai. Teknik penyusunan strategi yang digunakan adalah strategi pola interaksi. Berdasarkan teknik tersebut diformulasikan strategi seperti pada Tabel 1.

Berdasarkan Tabel 1 dapat diketahui kondisi kekuatan, kelemahan, peluang dan ancaman yang teridentifikasi dalam pengembangan usaha budidaya kepiting soka di Kota Banda Aceh. Formulasi strategi yang dilaksanakan dengan faktorfaktor yang telah diidentifikasi berdasarkan kondisi di lapangan maka dapat dirumuskan 4 strategi yang dapat dilaksankan dalam pengembangan budidaya kepiting soka. Strategi tersebut adalah:

1. Perluasan usaha budidaya kepiting soka dengan memanfaatkan informasi pasar dan program-program pemerintah yang menunjang

2. Pengarahan program-program pemerintah dan stakeholders terkait dalam meningkatkan penguasaan teknik budidaya kepiting soka dan membuka akses permodalan bagi pembudidaya

Tabel 1. Formulasi Strategi Optimalisasi Usaha Budidaya Kepiting Soka di Kota Banda Aceh. Table 1. Formulation Optimization Strategy Cultivation Crab Soft Shell in Banda Aceh.

\begin{tabular}{|c|c|c|}
\hline & Kekuatan (Strength) & Kelemahan (Weakness) \\
\hline $\begin{array}{l}\text { Faktor Eksternal/ } \\
\text { Eksternal Factor }\end{array}$ & $\begin{array}{l}\text { Ketersediaan lahan/ } \\
\text { Availability of land } \\
\text { Cita rasa produk kepiting } \\
\text { cangkang lunak bersaing/ } \\
\text { Excellence taste of soft shell crab } \\
\text { products } \\
\text { Keuntungan usaha prospektif/ } \\
\text { Prospective business advantage }\end{array}$ & $\begin{array}{l}\text { Rendahnya penguasaan SDM } \\
\text { terhadap teknik budidaya/ Low } \\
\text { techniques cultivation of human } \\
\text { resources } \\
\text { Besarnya modal yang diperlukan/ } \\
\text { The required of capital }\end{array}$ \\
\hline
\end{tabular}

Peluang (Opportunity)

- Pangsa pasar ekspor masih terbuka lebar/ Wide open export market share for crab product

- Program pemerintah dalam mendukung budidaya kepiting/ Government programs to support the cultivation of crab

\section{Ancaman (Threats)}

- Keterbatasan populasi benih kepiting/ Limitations of crab seed population

- Rentannya penyakit pada budidaya kepiting/ The volatility of the disease in the cultivation of crab
Perluasan usaha budidaya kepiting cangkang lunak dengan memanfaatkan informasi pasar dan program-program pemerintah yang menunjang/ Expansion of soft shell crab farming by using market information and government programs that support

Pemanfaatan ketersediaan lahan bagi usaha hatchery benih kepiting dan penelitian dan pengembangan teknik budidaya kepiting/ Utilization of land available to businesses crab hatchery rearing and research and development of cultivation techniques crab
Pengarahan program-program pemerintah dan stakeholders terkait dalam meningkatkan penguasaan teknik budidaya kepiting soka dan membuka akses permodalan bagi pembudidaya/ Provide direction for government programs and relevant stakeholders in improving soft-shelled crabs cultivation techniques and open access to capital for farmers

Peningkatan kualitas SDM dalam penguasaan teknologi budidaya kepiting yang mencakup teknologi penyediaan benih dan pencegahan penyakit/ Improved quality of human resources in the control of crab cultivation technology which includes the provision of seed technology and disease prevention

Sumber: Data Primer (Diolah,2013)/ Source: Primary Data (Processed, 2013) 
3. Pemanfaatan ketersediaan lahan bagi usaha hatchery benih kepiting dan penelitian dan pengembangan teknik budidaya kepiting

4. Peningkatan kualitas SDM dalam penguasaan teknologi budidaya kepiting yang mencakup teknologi penyediaan benih dan pencegahan penyakit

Keempat strategi yang telah dirumuskan diatas diharapkan dapat mengoptimalisasi peluang pengembangan budidaya kepiting soka dengan meminimalisasi ancaman dan kelemahan yang dimiliki dan dapat meningkatkan kesejahteraan masyarakat kelautan dan perikanan terutama di Kota Banda Aceh. Keberadaan KIMBis Cakradonya juga diarahkan dalam mempercepat implementasi strategi yang telah disusun dan mengkoordinasikanya dengan berbagai instansi yang terkait sehingga kebijakan dan programprogram yang dijalankan pemerintah dapat sejalan dengan strategi yang telah dirumuskan untuk dapat mengakselerasi usaha budidaya kepiting soka di Kota Banda Aceh.

\section{PENUTUP}

Kepiting soka atau juga dikenal dengan sebutan kepiting soka merupakan komoditas bernilai ekonomis tinggi. Ketersediaan lahan di Kota Banda Aceh sebagai lahan potensial untuk pengembangan usaha perikanan menunjang perluasan usaha budidaya kepiting soka di kawasan ini. Hal ini juga diperkuat dengan cita rasa kepiting soka yang dihasilkan di daerah ini yang relatif diminati oleh para konsumen terutama dari negara luar yang menyebabkan usaha ini menjadi prospektif untuk dikembangkan dalam rangka meningkatkan kesejahteraan masyarakat kelautan dan perikanan.

Keberadaan KIMBis Cakradonya di Kota Banda Aceh sebagai sebuah lembaga yang bertujuan untuk mendorong kemandirian masyarakat pedesaan diharapkan dapat meningkatkan pemanfaatan peluang budidaya kepiting soka di Kota Banda Aceh. Kegiatan yang telah dilaksanakan oleh KIMBis Cakradonya dalam optimalisasi peluang pengembangan kepiting soka diantaranya melalui sosialisasi dengan SKPD di Provinsi Aceh terkait prospek pengembangan kepiting soka yang mendatangkan narasumber yang kompeten, selain itu juga dikenalkan teknologi pengolahan limbah hasil budidaya kepiting soka sehingga dapat meningkatkan nilai tambah usaha ini dan menarik minat masyarakat dalam usaha pengembangan ekonomi masyarakat, selain itu kegiatan lain yang dirasa penting adalah pengenalan teknologi budidaya kepiting soka diantaranya adalah teknologi IMTA, teknologi hatchery dan juga teknologi ekstrak bayam yang diharapkan dapat menjadi solusi permasalahan yang dihadapi pembudidaya dalam melakukan usahanya. Hasil penelitian menunjukkan kegiatan yang dilakukan oleh KIMBis Cakradonya dalam optimalisasi usaha budidaya kepiting soka direspon dengan baik oleh kelompok sasaran namun diperlukan tindak lanjut untuk menjamin keberlanjutan komitmen terutama dari para pengambil kebijakan.

Formulasi strategi dari identifikasi kondisi di lokasi dan hasil pelaksanaan kegiatan dari KIMBis merumuskan beberapa strategi yang dapat mengoptimalisasi pengembangan usaha ini diantaranya adalah perlunya akses terhadap informasi pasar dan pengarahan programprogram pemerintah dan stakeholders terkait dalam meningkatkan penguasaan teknik budidaya kepiting soka dan membuka akses permodalan bagi pembudidaya. Selain itu strategi lain yang dapat diterapkan adalah meniningkatkan kualitas SDM dalam penguasaan teknologi budidaya kepiting yang mencakup teknologi penyediaan benih dan pencegahan penyakit. KIMBis Cakradonya diharapkan dapat mengakselerasi implementasi strategi yang telah dirumuskan tersebut sehingga pengembangan usaha budidaya kepiting soka di Kota Banda Aceh dapat meningkatkan kesejahteraan masyarakat kelautan dan perikanan.

Saran yang dapat diterapkan berdasarkan hasil penelitian diatas adalah KIMBis Cakradonya dapat melakukan berbagai kegiatan sebagai berikut sebagai bentuk langkah tindak lanjut bagi upaya optimalisasi peluang pengembangan kepiting soka di Kota Banda Aceh:

- Mendorong komitmen Balai Perikanan Air Payau Ujung Batee dalam menyediakan benih kepiting bakau bagi pembudidaya

- Mendorong kerjasama berbagai instansi pemerintah dalam mengembangkan design hatchery dan tambak yang efisien untuk produksi kepiting

- Melakukan pendampingan bagi pelaku usaha kepiting soka dalam mengembangkan akses terhadap informasi pasar yang potensial 
Melakukan pendampingan bagi pelaku usaha kepiting soka dalam mengakses permodalan

- Meningkatkan peran kelompok-kelompok usaha dalam budidaya kepiting soka sehingga dapat meningkatkan kapasitas usahanya dengan memanfaatkan input produksi secara lebih optimal

- Mengoptimalkan program berbantuan yang diberikan oleh berbagai instansi sehingga bantuan yang diberikan dapat tepat sasaran dan berperan dalam memanfaatkan peluang pengembangan usaha budidaya kepiting soka

\section{DAFTAR PUSTAKA}

Badan Pusat Statistik Kota Banda Aceh. 2011. Banda Aceh Dalam Angka Tahun 2011. Banda Aceh: Badan Pusat Statistik Kota Banda Aceh.

Cholik F and Hanafi A. 2005. Review of Mud Crab Culture Research in Indonesia, Central Research Institute for Fisheries, PO Box 6650 Slipi, Jakarta, Indonesia, 310 CRA.

Dinas Kelautan Perikanan dan Pertanian Kota Banda Aceh. 2012. Potensi Bidang Kelautan dan Perikanan. Banda Aceh: Dinas Kelautan Perikanan dan Pertanian Kota Banda Aceh.

Ditjen P2HP. 2011. P2HP Dalam Angka 2010. Direktorat Jenderal Pengolahan dan Pemasaran Hasil Perikanan Kementerian Kelautan dan Perikanan. Jakarta.

Ditjen Perikanan Budidaya.2013. Data Statistik Tahunan Produksi Perikanan Budidaya Indonesia. Kementrian Kelautan dan Perikanan. Jakarta

Ellis ED and Mantel HL. 1985. Integument, Pigment and Hormonal Processes. Florida: Academic Press Inc. Orlando.

Harahap, Muharram F., Thamrin, Bahri, S., 2013. Pengolahan Limbah Ikan Patin Menjadi Biodiesel.Pusat Penelitian Lingkungan Hidup Universitas Riau. Riau
Juwana, S. 1992. Produksi Benih Kepiting (Portunus Trituberculatus) Pada Beberapa Hatchery Di Jepang. Pusat Penelitian Oseanografi-LIPI. Buletin IImiah Oseana. VolXVI (1): 31-34. Jakarta.

KKP. 2012. Statistik Perikanan. Pusat Data dan Informasi, KKP, Jakarta

Multazam. 2002. Prospek pemanfaatan cangkang rajungan (Portunus sp.) sebagai suplemen pakan ikan (skripsi). Bogor. Fakultas Perikanan dan IImu Kelautan, Institut Pertanian Bogor. Bogor

Nickols, F. 2000. Strategy Is A Lot of Things. http:// home.att.net/-nickols/strategy_is.htm Juli 2013].

Nurdin M, Armando R. 2010. Cara Cepat Panen Kepiting Cangkang lunak dan Kepiting Telur. Penebar Swadaya. Jakarta.

Patton, M.Q. 2001. Qualitative Research and Evaluation Methods. 3rd edition. New York: Sage Publication. Inc

Rangkuti, F. 2000.Analisis SWOTTeknik Membedah Kasus Bisnis. PT Gramedia Pustaka Utama, Jakarta.

Siahainenia, S. 2008. Aspek Bioekologi Kepiting Bakau (Scylla spp.) di Ekosistem Mangrove. Kabupaten Subang, Jawa Barat [Disertasi]. Sekolah Pascasarjana, Institut Pertanian Bogor.

Sugama, Ketut. 2013. Peluang Pengembangan Budidaya Kepiting Cangkang lunak Untuk Menambah Pendapatan Masyarakat Provinsi Nangro Aceh Darussalam. Materi Presentasi. Banda Aceh 06 September 2013.

Susanto. G. Nugroho, 2008, Peneluran Kepiting Bakau (Scylla sp.) dalam Kurungan Bambu Di Tambak berdasarkan Pengamatan Tingkat Kematangan Gonad, Universitas Lampung, Lampung. 